\title{
1 Variable freshwater influences on the abundance of Vibrio vulnificus in a
}

2 tropical urban estuary

4 Olivia D. Nigro ${ }^{1}$, La’Toya I. James-Davis ${ }^{2,3 \dagger}$, Eric Heinen De Carlo ${ }^{3}$, Yuan-Hui Li ${ }^{3}$, Grieg

$5 \quad$ F. Steward $2,3 *$

6

7 1Department of Natural Science, Hawai'i Pacific University, Honolulu, HI

8 2Daniel K. Inouye Center for Microbial Oceanography-Research and Education,

9 School of Ocean and Earth Science and Technology (SOEST), University of Hawai'i at

10 Mānoa, Honolulu, Hawai'i

11 32Department of Oceanography, School of Ocean and Earth Science and Technology

12 (SOEST), University of Hawai'i at Mānoa, Honolulu, Hawai'i

13

14 †Present address: 3551 Roger Brooke Drive, JBSA Ft. Sam Houston, San Antonio, TX

1578234

16

17 *Contact: Phone 808-354-1652; email grieg@hawaii.edu

18

19 


\section{ABSTRACT}

To better understand the controls on the opportunistic human pathogen

22 Vibrio vulnificus in warm tropical waters, we conducted a year-long investigation in

23 the Ala Wai Canal, a channelized estuary in Honolulu, HI. The abundance of $V$.

24 vulnificus as determined by qPCR of the hemolysin gene ( $v v h A)$, varied spatially and

25 temporally nearly four orders of magnitude ( $\leq 3$ to $14,000 \mathrm{~mL}^{-1}$ ). Unlike in

26 temperate and subtropical systems, temperatures were persistently warm (19-

$27 \quad 31^{\circ} \mathrm{C}$ ) and explained little of the variability in $V$. vulnificus abundance. Salinity (1-36

28 ppt) had a significant, but non-linear, relationship with $V$. vulnificus abundance with

29 highest $v v h A$ concentrations $\left(>2,500 \mathrm{~mL}^{-1}\right)$ observed only at salinities from 7 to 22

30 ppt. $V$. vulnificus abundances were lower on average in the summer dry season

31 when waters were warmer but more saline. Highest canal-wide average abundances

32 were observed during a time of modest rainfall when moderate salinities and

33 elevated concentrations of reduced nitrogen species and silica suggested a

34 groundwater influence. Distinguishing the abundances of two genotypes of $V$.

35 vulnificus (C-type and E-type) suggest that C-type strains, which are responsible for

36 most human infections, were usually less abundant (25\% on average), but their

37 relative contribution was greater at higher salinities, suggesting a broader salinity

38 tolerance. Generalized regression models suggested up to $67 \%$ of sample-to-sample

39 variation in log-transformed $V$. vulnificus abundance was explained $(\mathrm{n}=202)$ using

40 the measured environmental variables, and up to $97 \%$ of the monthly variation in

41 canal-wide average concentrations $(n=13)$ was explained with the best subset of

42 four variables.

\section{IMPORTANCE}

Our data illustrate that, in the absence of strong seasonal variation in water

45 temperature in the tropics, variation in salinity driven by rainfall becomes a primary

46 controlling variable on $V$. vulnificus abundance. There is thus a tendency for a

47 rainfall-driven seasonal cycle in $V$. vulnificus abundance that is inverted from the 
48 temperature-driven seasonal cycle at higher latitudes. However, stochasticity in

49 rainfall and its non-linear, indirect effects on $V$. vulnificus concentration means that

50 high abundances can occur at any location in the canal at any time of year, making it

51 challenging to predict concentrations of this pathogen at high temporal or spatial

52 resolution. Much of the variability in canal-wide average concentrations, on the

53 other hand, was explained by a few variables that reflect the magnitude of

54 freshwater input to the system, suggesting that relative risk of exposure to this

55 pathogen could be predicted for the system as a whole.

\section{INTRODUCTION}

The bacterium $V$. vulnificus is an opportunistic and formidable human

58 pathogen that has a world-wide distribution, in a variety of marine and estuarine

59 environments (1). In humans, $V$. vulnificus may cause a range of illnesses that

60 includes gastroenteritis, necrotizing fasciitis, and septicemia (2). Infections occur as

61 a result of ingestion of contaminated seafood (3) or via wound exposure to waters

62 (4). Strains vary in their propensity to cause disease in humans, with certain

63 genotypically distinguishable strains much more commonly, but not exclusively,

64 associated with disease in humans (5). The exact mechanisms of virulence in $V$.

65 vulnificus, and the genes responsible for the onset of illness, have yet to be

66 determined, but a number of correlative biomarkers have been used to discriminate

67 those strains most commonly associated with human disease (6). Variations in the

68 16S rRNA gene, for example, have been used in PCR assays to discriminate "A-type"

69 strains from "B-type" strains $(7,8)$, the latter of which predominate among clinical

70 isolates. Another commonly used marker is the $200 \mathrm{bp}$ segment of the virulence-

71 correlated gene that resolves the gene variants $v c g C$ or "C-type" strains from $v c g E$ or

72 "E-type" strains (9). PCR-based analysis of fifty-five V. vulnificus isolates indicated

73 that $90 \%$ of the strains isolated from infected patients were of the C-type (clinical),

74 while $93 \%$ of the strains isolated from the environmental samples were E-type

75 (environmental). Subsequent analyses revealed broader genomic differences along

76 with physiological differences between these lineages suggesting that they are 
77 distinct ecotypes that may be better adapted for either environmental growth (E-

78 type) vs. stress tolerance (C-type) (10). These biomarkers are largely congruent,

79 with the common environmental strains being A-type/E-type, and the majority of

80 clinical isolates being B-type/C-type, although all types can cause disease in humans

81 (11).

82 Studies of $V$. vulnificus in temperate and subtropical waters have shown that

83 warmer temperatures increase the frequency of detection (12-15). Quantification

84 over an annual cycle reveals a clear temperature-driven seasonal signal, with the

85 highest concentrations of $V$. vulnificus occurring in warm summer months (16-19)

86 and culturable cells declining dramatically at temperatures below $13{ }^{\circ} \mathrm{C}(6) . V$.

87 vulnificus abundance is also influenced by salinity (19-21), thriving in conditions of

88 both warm temperatures and moderate salinities (5). The environmental patterns of

89 abundance are consistent with observations of $V$. vulnificus growth under controlled

90 laboratory conditions $(12,22)$ that show increasing growth rates up to around 37

$91{ }^{\circ} \mathrm{C}$, and a broad salinity tolerance with fastest growth rates between $5-25 \mathrm{ppt}$.

92 Correlation models of environmental data support the idea that temperature and

93 salinity are two of the most important variables controlling $V$. vulnificus abundance,

94 but their relative importance depends on the ranges over which they are sampled.

$95(21,23-26)$.

96 In temperate environments, the incidence of $V$. vulnificus infection tracks the

97 seasonal environmental abundances of the pathogen, with the most infections

98 occurring during the warm summer months (6). It follows that the inhabitants of

99 sub-tropical, and especially tropical areas, where air and water temperatures are

100 warm year-round, would be particularly vulnerable to V. vulnificus infection. Indeed,

101 according to available surveillance data for the years 2003-2008 (27-29), Hawai'i

102 had the fifth highest incidence of non-food-borne $V$. vulnificus infections in the U.S.,

103 trailing only four gulf states (Florida, Louisiana, Mississippi, and Texas). When we

104 convert these to a per capita basis, it was the highest in the nation. Despite higher

105 incidence of $V$. vulnificus wound infections, primarily from recreational waters, there

106 has been little data collected on Vibrio vulnificus in the coastal waters of Hawai'i (30,

10731 ) and scant data on the ecology of V. vulnificus in tropical waters in general (20). 
108 Consequently, we initiated an investigation of the abundance and dynamics of $V$.

109 vulnificus in the Ala Wai Canal and Harbor.

110 The Ala Wai canal provides partially channelized drainage for two

111 watersheds. Although it is not designated as a recreational waterway, the canal is

112 used extensively for boating and fishing. Flow down the canal varies as a function of

113 tide and of rainfall, the latter driving surface runoff (streams and storm drains) and,

114 with some hysteresis, groundwater seepage. Salinity varies widely in the canal, as a

115 function of depth, overall stream flow, position in the canal relative to the

116 freshwater sources, and tidal forcing. Water temperature, on the other hand, varies

117 over a relatively narrow range compared to temperate systems. Because of the

118 seasonality in rainfall in Hawaii, with higher precipitation in winter months (32), we

119 hypothesized that there could be an inverse seasonal pattern in $V$. vulnificus

120 abundance driven by salinity compared to the strongly temperature-driven patterns

121 in temperate waters.

122 Our objectives with this study were to document the temporal spatial

123 variability of $V$. vulnificus total abundance and strain composition (C-type vs. E-

124 Type) in the estuarine waters of the Ala Wai Canal and Harbor and to determine

125 how abundance was related to environmental variables. The goal was to better

126 understand the environmental controls on $V$. vulnificus in tropical estuarine waters

127 and to assess the prospects for modeling pathogen abundance.

\section{MATERIALS AND METHODS}

\section{Study Site}

130 Sampling took place in the Ala Wai Canal (Fig. 1), a $3.1 \mathrm{~km}$ long, engineered

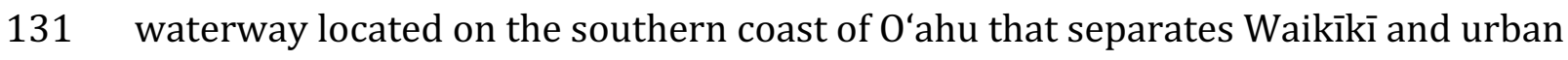
132 Honolulu (33). A watershed that covers $42.4 \mathrm{~km}^{2}$ drains into the Ala Wai Canal via 133 the Mānoa and Pālolo Streams, which merge to form the Mānoa-Pālolo Stream prior

134 to entering the canal, and the Makiki Stream, all of which run through urban areas

135 before reaching the canal. As a consequence, the streams are contaminated with a 
136 variety of anthropogenic substances and their convergence in the Ala Wai Canal has

137 contributed to its pollution and eutrophication $(34,35)$. The influx of fresh water

138 from the streams creates a salinity gradient with a typical salt-wedge structure.

139 Tidal flow causes seawater to flow landward on the flood tide and seaward on the

140 ebb tide and remain at depth. The freshwater streams flow seaward on all tides

141 creating a freshened water surface layer estimated to extend to $0.5 \mathrm{~m}$ depth on

142 average, but which is highly variable both in salinity and thickness (36). Sediments

143 are continually deposited in the canal at the mouth of the Mānoa-Pālolo Stream

144 causing the build-up of a sill that restricts flushing of deep water in the uppermost

145 section of the canal.

\section{Sampling locations, dates, and times}

147 Sampling of the Ala Wai Canal spanned 13 months beginning March 17, 2008

148 and concluding on March 10, 2009, covering the nominal dry summer (April-

149 September) and rainy winter (October-March) months. Samples were collected

150 monthly at twelve sites in the Ala Wai Canal numbered (1 and 5-15) by distance

151 from the shallow, upper section of the canal (Site 1) to the Ala Wai Harbor (Site 15).

152 Site 9 was just inside the mouth of Mānoa-Pālolo Stream and Site 12 was at the

153 mouth of Makiki Stream (Fig. 1, Supplemental Table S1). Missing site numbers 2-4

154 referred to other samplings at Site 1 that were not used in this study. Sampling at a

155 higher temporal resolution was also conducted in the dry and rainy seasons to

156 assess changes on shorter time scales. Samples were collected weekly at all sites for

157 four weeks from June 26-July 17, 2008 and again for three weeks from February

158 22-March 10, 2009. Samples were also collected at a reduced number of sites (Sites

$1595,9,12,14)$ daily for six days from July 10-15, 2008 and daily for five days from

160 March 2-6, 2009, and once every three hours (trihoral) for twenty-four hours at

161 Sites 5, 9, and 14 from July 15 to July 16, 2008.

\section{Rainfall and streamflow}

163 Rainfall data collected by National Weather Service rain gauges (part of the

164 Hawai'i Hydronet System) at 15-minute intervals were retrieved from the online 
165 resource (https://www.weather.gov/hfo/hydronet-data). Data from two gauges

166 were selected for analysis. The first was HI-18 (NOAA\# MNLH1), which is located

167 near the origin of Mānoa Stream (N21.3161 W157.8142) at an elevation of $150 \mathrm{~m}$ in

168 Manoa Valley ("Valley" rainfall). The second is HI-26 (ALOH1), which is located at

169 Aloha Tower (N21.3060 W157.8662) in downtown Honolulu near sea level (15 m)

170 at the coast ("Coastal" rainfall). From these data, average daily rainfall for all

171 sampling months was determined, as well as total rainfall from each 24-hour period

172 prior to sampling. Data on tidal flux were obtained from the National Ocean Service

173 (NOS), using tide gauge number 1612340. Stream flow data were obtained from the

174 United States Geological survey (waterdata.usgs.gov/usa/nwis/uv?16247100) for

175 the Mānoa-Pālolo Stream gauge \#16247100.

\section{Water sample collection and processing}

177 Whole water samples were collected from the top 10-30 cm at all sites in

178 acid-washed bottles with a pole sampler and stored on ice (except for samples used

179 for culturing, which were kept at $\sim 15{ }^{\circ} \mathrm{C}$ with cold packs) and transported to the

180 laboratory within three hours of collection. Subsamples (ca. $25 \mathrm{~mL}$ ) for nutrient

181 analysis $(n=207-211)$ were frozen and shipped on dry ice to the Oregon State

182 University nutrient analysis facility for determination of dissolved silica, phosphate,

183 nitrate plus nitrite, nitrite, and ammonium concentrations (37). Nutrient

184 concentrations were measured during every sampling event excluding two weekly

185 sampling events in July 2008 (July 3 and 7). The values for the mean, number of

186 samples, median, minimum and maximum of the measured nutrients have been

187 previously reported (38).

188 For particulate carbon (PC) or nitrogen (PN) and chlorophyll a (chl a)

189 measurements, subsamples (25-200 ml) were filtered onto pre-combusted glass-

190 fiber filters (GF/F, Whatman) in duplicate and stored frozen until analysis. For PC

191 and PN ( $\mathrm{n}=199)$, filters were pelletized and combusted in a high-temperature

192 combustion CN analyzer, the CE-440 CHN elemental analyzer (Exeter Analytical)

193 following HOT program protocols (39). Filters for chl a analysis $(n=194)$ were

194 extracted in $100 \%$ acetone at $-20^{\circ} \mathrm{C}$ for 7 days. Fluorescence of extracts and 
195 standards were measured using a Turner AU10 fluorometer before and after

196 acidification (40).

197 Samples for bacteria counts $(\mathrm{n}=219)$ were fixed with filtered $(0.2 \mu \mathrm{m})$

198 formaldehyde (10\% w/v final concentration) in a cryovial (Nalgene) and stored at -

$19980^{\circ} \mathrm{C}$. Total bacteria were counted by thawing samples, staining with SYBR Green I,

200 and analyzing on an acoustic focusing flow cytometer (Attune; Thermo Fisher

201 Scientific).

202 Samples for molecular analysis (100-550 mL) were pressure filtered via

203 peristaltic pump through $0.22 \mu \mathrm{m}$ polyethersulfone filter capsule (Sterivex,

204 Millipore), then stored at $-80^{\circ} \mathrm{C}$ until extracted.

\section{Cultivation on vibrio selective medium}

206 For five of the monthly samplings (Mar, Jun, Sep, Dec 2008, and Mar 2009),

207 water samples were filtered through $0.45 \mu \mathrm{m}$ pore size, mixed cellulose ester filters

208 (47 mm, GN-6; Pall) and filters were placed face-up on the vibrio-selective medium

209 CHROMagar Vibrio (DRG Intl.). After overnight incubation, blue colonies were

210 enumerated as putative $V$. vulnificus.

\section{DNA extraction and purification}

212 DNA was extracted from the Sterivex filters using the Masterpure ${ }^{\mathrm{TM}}$ Nucleic

213 Acid Extraction Kit (Epicentre). Six-hundred microliters of Masterpure ${ }^{\mathrm{TM}}$ Tissue and

214 Cell Lysis Solution containing recommended quantities of proteinase K were added

215 to each Sterivex filter. The ends of the filters were sealed and the filters incubated

216 on a rotisserie in a hybridization oven at $65^{\circ} \mathrm{C}$ for 15 minutes. Fluid was recovered

217 from filter housing by aspiration with a syringe. The filling with buffer, incubation,

218 and buffer recovery steps were repeated twice more and the combined extract from

219 all three rounds was pooled (total volume ca. $1.8 \mathrm{ml}$ ). Three-hundred microliters of

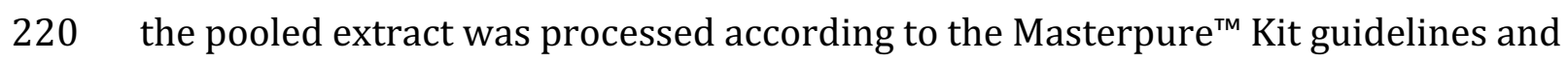

221 the remainder was archived. Accounting for all of the raw extract volume, total DNA

222 yields ranged from 1-540 $\mathrm{g} \mathrm{L} \mathrm{L}^{-1}$ of canal water (geometric mean of $30 \mu \mathrm{g} \mathrm{L}^{-1}$ ).

223 Following initial purification, the resuspended DNA (200 $\mu \mathrm{L})$ was passed through a 
224 spin column containing acid-washed polyvinylpolypyrrolidone (PVPP) in an effort

225 to remove any residual inhibitors (41). DNA concentration in each sample was

226 quantified fluorometrically (Quant-iT Broad Range DNA kit, Life Technologies) both

227 before and after the PVPP purification step to account for losses incurred during the

228 purification stage (average recovery 60\%). Geometric mean concentration of DNA in

229 the final purified extracts was $7 \mathrm{ng} \mu \mathrm{L}^{-1}$ (range $0.1-54 \mathrm{ng} \mu \mathrm{L}^{-1}$ ).

\section{Quantitative PCR}

231 Total V. vulnificus was estimated by TaqMan qPCR targeting the hemolysin 232 gene $(v v h A)$ using primer and probe sequences reported by Campbell and Wright

233 (42). Quantification of C-type V. vulnificus used the primers and probes targeting the 234 virulence-correlated gene variant $(v c g C)$ from Baker-Austin et al. (43). E-type $V$.

235 vulnificus was calculated as the difference in concentration between the two assays.

236 Both assays were prepared as $25-\mu \mathrm{L}$ reactions with $12.5 \mu \mathrm{L}$ of TaqMan Universal

237 PCR Master Mix (Applied Biosystems), $1.5 \mu \mathrm{g} \mu \mathrm{l}^{-1}$ final concentration of non-

238 acetylated bovine serum albumin (Applied Biosystems) and 0.25-0.9 $\mu \mathrm{M}$ each of the

239 appropriate primers and probe (Supplemental Table S2), 2-5 $\mu$ l of DNA template,

240 and water as needed. For $v v h A$ assay, primers were added at $0.9 \mu \mathrm{M}$ each and the

241 probe at $0.25 \mu \mathrm{M}$. For the $v c g C$ assay, primers and probe were each added at $0.5 \mu \mathrm{M}$

242 final concentrations. Cycling conditions consisted of initial denaturation at $95{ }^{\circ} \mathrm{C}(10$

$243 \mathrm{~min})$, then 40 cycles of $95^{\circ} \mathrm{C}(15 \mathrm{~s})$ and $60^{\circ} \mathrm{C}(60 \mathrm{~s})$. All qPCR reactions were

244 performed in triplicate with DNA template in the final replicate diluted 10-fold (up

245 to 50-fold) to check for inhibition (44) and with additional replication as needed to

246 repeat inhibited samples at the higher dilutions. The cycling protocol consisted of an

247 initial denaturation at $95^{\circ} \mathrm{C}$ for 10 minutes, followed by 40 cycles of $95{ }^{\circ} \mathrm{C}$ for $15 \mathrm{~s}$

248 and $60{ }^{\circ} \mathrm{C}$ for $60-90 \mathrm{~s}$. The amplified PCR product was detected by monitoring the

249 increase in fluorescence signal generated from the 6-carboxyfluorescein-labeled

250 probe using a Realplex ${ }^{2}$ Mastercycler (Eppendorf). Data were analyzed using

251 realplex software (Eppendorf) to determine cycle threshold $\left(\mathrm{C}_{\mathrm{t}}\right)$ values. A standard

252 curve of serial 10-fold dilutions of genomic DNA (V. vulnificus strain YJ016) was run

253 in triplicate along with the samples. 


\section{Statistical treatment of data}

255 Statistical analyses were conducted using JMP Pro 15 (SAS Institute, Inc.).

256 Concentrations of $V$. vulnificus (CFU or $v v h A$ gene copies $\mathrm{mL}^{-1}$ ), total bacteria, $\operatorname{chl} a$,

257 nutrients, PC, and PN were log transformed and rainfall and streamflow were cube-

258 root transformed in order to normalize the data for multivariate analyses. For some

259 analyses, sites were clustered into categories of "Upper canal" (Sites 1,5-8) and

260 "Lower canal" (Sites 10,11,13-15) based on whether they were landward or

261 seaward of the sediment sill deposited at the mouth of the Mānoa-Pālolo Stream.

262 Comparison of means between two samples were conducted with t-tests assuming

263 unequal variance or by the non-parametric Komlgorov-Smirnov Asymptotic Test for

264 data that could not be readily normalized by transformation. Comparisons of means

265 among three or more samples were conducted by ANOVA with a post-hoc Tukey-

266 Kramer test of honestly significant difference. Factor analysis was conducted on

$267 v v h A$ and nutrient data using principal components with varimax rotation. For

268 multiple linear regression, the data were split into two subsets (salinity $<12$ or $\geq 12$

269 ppt), because of the non-linearity in the relationship between $V$. vulnificus and

270 salinity (21). Multiple linear regression models were also conducted on data

271 covering the entire salinity range by either including a quadratic term for salinity

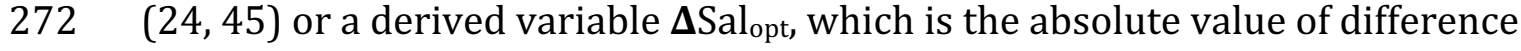

273 between the sample salinity and an optimum salinity set as 12 ppt (46). Variables

274 for constructing generalized regression models on each subset were selected using

275 the Akaike Information Criterion by screening for the subsets that produced the best

276 fit among all possible models. Among equivalent subsets in the "green zone" (AICc to

277 AICc+4), either the subset with the best fit or with the fewest variables was selected

278 as noted in the text.

279 Out of 243 total qPCR assays for $V$. vulnificus abundance, seventeen (ca. 7\%)

280 had issues that made them unreliable or unavailable (inhibition, below the reporting

281 limit for the assay, or absence of data). In thirteen of these instances, abundances

282 were instead inferred from blue colony counts on CHROMagar Vibrio medium

283 (Supplemental Methods), based on the strong correlation ( $r=0.8)$ between log- 
284 transformed concentrations of blue colony counts and vvhA gene copy numbers

285 (Supplemental Fig. S1).

\section{RESULTS}

\section{Variability of the habitat}

288 Rainfall in Mānoa Valley, one of the major watersheds draining into the canal, 289 varied from 0 to $15.8 \mathrm{~cm}$ in the 24-hour period preceding each sampling event. The 290 average rainfall prior to samplings in the rainy season (Oct-Mar) was $3.7 \mathrm{~cm}$, which 291 was significantly higher $(\mathrm{p}=0.0054)$ by an order of magnitude compared to the 292 average in the dry season (Apr-Sep) of $0.27 \mathrm{~cm}$ (Supplemental Figure S2). Flow 293 from the Mānoa-Pālolo Stream varied from 0.4 to $2.6 \mathrm{~m}^{3} \mathrm{~s}^{-1}$ on sampling days and 294 was strongly correlated with the prior 24-hr rainfall in Mānoa Valley $(\mathrm{r}=0.87, \mathrm{n}=$ 295 13, $p=<0.0001$; Supplemental Table S3). Both the canal-wide average salinity and 296 temperature for the monthly samplings $(n=13)$ had significant negative

297 correlations with prior 24-hr rainfall $(\mathrm{r}=-0.84, p=0.0003$ and $\mathrm{r}=-0.86, p=0.0002$, 298 respectively).

299 Over the course of the 13-month study, measured surface water salinities in 300 the Ala Wai Canal varied from 1 to $36 \mathrm{ppt}$ (mean of $24 \mathrm{ppt}$ ) and temperatures from 30119.2 to $31.8^{\circ} \mathrm{C}$ (mean of $27^{\circ} \mathrm{C}$; Table 1). Salinity was highly variable throughout the 302 study area reaching maxima of $\geq 29$ ppt at every site and minima of $\leq 5 \mathrm{ppt}$ at least 303 once at each site except Site 15, which is the most seaward site in the harbor 304 (minimum salinity of $11 \mathrm{ppt}$ ). Consequently, there was no significant difference in 305 average salinity among sites (ANOVA, $p>0.07$ ). When samples were clustered by 306 general location, average salinity in the upper and lower canal were not significantly 307 different $(p=.7818)$, but the combined stream mouth sites had significantly lower 308 salinity on average than either the upper $(\mathrm{p}=.0083)$ or lower $(\mathrm{p}=.0016)$ canal sites.

309 All of the measured variables (Table 1) except silica and nitrite displayed 310 overall significant positive or negative significant correlations with salinity 311 (Supplemental Table S4), but the correlation coefficients were low in many cases 
312 because of non-linearity in the relationships (Fig. 2). Temperature displayed a

313 significant, linear positive correlation with salinity $(\mathrm{r}=0.65, \mathrm{n}=242, \mathrm{p}<.0001)$.

314 Correlation and regression analyses for all other variables vs. salinity are reported

315 for log transformed data. Concentrations of chl $a$ (range 0.4-512 $\mu \mathrm{g} \mathrm{L}^{-1}$ ) showed a

316 significant positive, linear (Fig. 2a) correlation with salinity ( $r=0.49, \mathrm{n}=194, \mathrm{p}<$

3170.0001 ). Concentrations of total bacteria (range $0.47 \times 10^{6}$ to $11 \times 10^{6} \mathrm{~mL}^{-1}$ ) also

318 showed a significant positive correlation with salinity $(r=0.29, n=219 ; p<0.0001)$,

319 but the relationship was non-linear (Fig. 2c). Particulate carbon (range 15-5,600

$320 \mu \mathrm{M}$ ) had a non-linear relationship with salinity (Fig. 2d) that resulted in an overall

321 weak but significant negative correlation ( $\mathrm{r}=-0.25, \mathrm{n}=199, \mathrm{p}=0.0003)$.

322 Of the dissolved inorganic nutrients, only phosphate (range $0.2-8.7 \mu \mathrm{M}$ ) had

323 a linear relationship with salinity (Fig. 2e) and displayed a significant negative

324 correlation $(r=-0.46, n=211, p<0.0001)$. Concentrations of silica $(11-490 \mu \mathrm{M})$,

325 nitrate $(0.02-260 \mu \mathrm{M})$, nitrite $(0.04-3.3 \mu \mathrm{M})$, and ammonia (0.94-22 $\mu \mathrm{M})$ all

326 displayed significant, non-linear relationships with salinity (Fig. 2f-i), with highest

327 values occurring at moderate salinities. Despite the non-linear relationships, there

328 were significant negative correlations between salinity and either nitrate $(r=-0.32$,

$329 \mathrm{p}<0.0001)$ or ammonia $(\mathrm{r}=-0.44, \mathrm{p}<0.0001)$. Silica and nitrite, on the other hand,

330 showed highly significant, non-linear relationships with salinity (Fig. 2f, h), that

331 resulted in low and insignificant correlation coefficients.

332 When sites were clustered by location, most nutrients (nitrate, ammonia,

333 phosphate, silica, but not nitrite), particulate carbon, chl $a$, and total bacteria were

334 all significantly higher $(\mathrm{p}<0.01)$ in the upper canal sites than the lower canal sites.

\section{Temporal and spatial variability of $V$. vulnificus}

336 Concentrations of the $v v h A$ gene (a proxy for $V$. vulnificus abundance) varied

337 over several orders of magnitude in space and over time (Fig. 3) from 3 to 13,700

$338 \mathrm{~mL}^{-1}$ with overall geometric mean concentration for all samplings of $68 \mathrm{~mL}^{-1}(\mathrm{n}=$

339 239; Table 1). Concentrations of $v v h A$ at any given site were highly variable over

340 time with values that were above average or below average occurring at some point

341 at every location. Although spatial and temporal variability were low during the 
342 trihoral sampling over the course of one day in July, larger variations were seen on

343 daily or longer time scales. The most dramatic variation is the change from above

344 average to below average concentrations at every site in the span of 15 days

345 (October 27 to November 11, 2008).

346 Despite the high variability, average log-transformed $v v h A$ concentrations in

347 the rainy season $(1.98 \pm 0.72)$ were significantly higher (unpaired t-test, $p=.0013$ )

348 than the dry season (1.72 \pm 0.50 ; Supplemental Fig. S2). None of the individual

349 sites had an annual average $v v h A$ concentration that was significantly different from

350 any of the others (ANOVA, post-hoc Tukey, $p \geq .63$ ). However, excluding the stream

351 mouth sites, the annual average concentration of log-transformed $v v h A$ for the five

352 sites in the upper canal (2.04 \pm 0.74 ) was significantly higher ( $\mathrm{n}=65$ at each site;

353 unpaired t-test, $p=.0110$ ) than the annual average for five sites in the lower canal

$354(1.75 \pm 0.70)$.

\section{Relationship of $\boldsymbol{V}$. vulnificus to temperature and salinity}

356 Log-transformed concentrations of $v v h A$ displayed a weak, but significant, 357 negative correlation ( $\mathrm{r}=-0.174, p=.0071)$ with temperature (Fig 4a). However,

358 partial correlation analysis indicates that the relationship between $\log [v v h A]$ and

359 temperature is weakly positive, but significant $(\mathrm{r}=0.258, p<.0001)$ when

360 accounting for the effect of salinity and other variables. The relationship of

$361 \log [v v h A]$ with salinity was non-linear with a peak around 12 ppt (Fig. 4b). Linear

362 regression analysis for samples having a salinity either $<12$ or $\geq 12$ ppt showed that

$363 v v h A$ increased significantly $\left(\mathrm{r}^{2}=0.315\right.$; F test, $\left.p=.0001\right)$ as a function of salinity

364 over the lower range and decreased significantly $\left(\mathrm{r}^{2}=0.492 ; \mathrm{F}\right.$ test $\left.p<.0001\right)$ over

365 the higher range.

366 Concentrations of clinical, or C-type, $V$. vulnificus were usually lower than

367 those of environmental, or E-type, and accounted for $26 \%$ of the total V. vulnificus on

368 average across all samplings for which data were available $(n=219)$, indicating that

369 communities were most often dominated by E-type. Both C-type and E-type $V$.

370 vulnificus were most abundant at moderate salinities and declined as a function of 
371 salinity, but C-type declined at a lower rate. As a result, the contribution of C-type

372 tended to increase as a function of salinity. Samples in which C-type accounted for

$373>50 \%$ of the total $(n=39)$ were only observed in higher salinity waters (Fig. 4 b) and

374 the \% C-type was significantly higher (Komolgorov-Smirnov; $p=0.0164$ ) in higher

375 salinity samples ( $\geq 25 \mathrm{ppt}, \mathrm{n}=146)$ than in samples having lower salinity $(<25 \mathrm{ppt}$,

$376 \mathrm{n}=73$; Supplemental Fig. S3).

\section{Relationship between $\boldsymbol{V}$. vulnificus and additional variables}

378 To understand additional factors that may be important in controlling $V$.

379 vulnificus in this habitat, factor analysis was conducted with $v v h A$, temperature,

380 salinity, and nutrient data (Fig. 5a). Two factors had eigenvalues $>1$. The strongest

381 positive correlations $(r \geq 0.4)$ were between $v v h A$ and silica or reduced nitrogen

382 species, which were associated with Factor 1, and strong negative correlations ( $\mathrm{r} \leq-$

3830.4 ) were found between salinity and $v v h A$, ammonia, and phosphate along Factor 2.

384 Plots of the factor loading values with points coded by rainfall and streamflow (Fig

$3855 \mathrm{~b}$ ) illustrate the relationship between indicators of freshwater input and salinity

386 along the Factor 2 axis. Coding the points by $\log v v h A$ concentration and silica

387 concentration illustrates the association of these variables (along with reduced

388 nitrogen species) with Factor 1. Overall the highest concentrations of $v v h A$ occurred

389 at moderate rainfall in the valley, but relatively low streamflow, and elevated

390 concentrations of silica.

391 Generalized regression models for predicting $v v h A$ concentrations over the

392 two different salinity ranges were constructed using the overall best subset $(<12$

393 ppt model) or the best subset having the minimum number of variables ( $\geq 12 \mathrm{ppt}$

394 model). Only properties intrinsic to the individual samples were included in this

395 analysis (i.e., tides, rainfall and streamflow were not considered). For samples with

396 salinities < 12 ppt ( $\mathrm{n}=39$ out of 41 samples, because of missing nutrient data) a

397 subset of four (temperature, nitrite, silica, and PC) out of eight variables explained

$39875 \%$ of the observed variation with the equation:

399

400

$$
\log [v v h A]=0.154 \bullet T+1.015 \bullet \log [\text { nitrite }]-0.600 \bullet \log [\text { silica }]-0.850 \bullet \log [P C]+2.170
$$


402 where $T$ is temperature in ${ }^{\circ} \mathrm{C}$, and nitrite, silica, and particulate carbon (PC) are in

403 units of $\mu \mathrm{M}$ (model fit illustrated in Supplemental Fig S4a). For samples with

404 salinities $\geq 12$ ( $\mathrm{n}=163$ out of 198 possible samples because of missing nutrient

405 data) a subset of just three (temperature, salinity and phosphate) out of seven

406 variables explained $55 \%$ of the variability:

407

$408 \log [v v h A]=0.0360 \bullet T-0.0727 \bullet S+0.515 \bullet \log [$ phosphate $]+2.835$

409 where $T$ is temperature in ${ }^{\circ} \mathrm{C}, S$ is salinity is in units of ppt, and phosphate is in units

410 of $\mu \mathrm{M}$ (model fit illustrated in Supplemental Fig. S4b). PC was removed prior to

411 variable selection in the latter model, because initial analysis showed it offered no

412 significant explanatory power at salinities $>12 \mathrm{ppt}$, and missing data would have

413 further restricted the samples included in the analysis. When predictions from the

414 two models were combined, $66 \%$ of the variability in $\log (v v h A)$ over the entire

415 salinity range was explained overall (Fig. 6).

416 Models in which either a quadratic term for salinity or the derived variable

$417 \Delta$ Sal $_{\text {opt }}$ were included explained similar amounts of variability $\left(r^{2}=0.61\right.$ and 0.63 ,

418 respectively; $p \leq .0001$ ) using different sets of five variables (Supplemental Fig. S5),

419 but were slightly outperformed by the combined models above.

\section{System-wide controls on $\mathrm{V}$. vulnificus}

421 To smooth out inter-station variability and focus on temporal variations in

$422 v v h A$, canal-wide averages for the variables for each monthly sampling were also

423 analyzed in relation to system-wide drivers of rainfall and streamflow (Fig. 7). In

424 general, average rainfall, streamflow, phosphate, silica, and $v v h A$ are all below

425 average, and salinity above average, during most of the dry season with minimal

426 variability. During the rainy season, periodic heavy rainfall resulted in high

427 variability with excursions in all variables well above and below their overall

428 averages. 
Three freshening events are evident from dips in the average salinity in the 430 canal during the rainy season (Fig. 7). The first begins in September and peaks in

431 October 2008 following increases in rainfall and streamflow. The average monthly

432 rainfall increased from $\leq 0.75 \mathrm{~cm} \mathrm{~d}^{-1}$ in the preceding months to $1.0 \mathrm{~cm} \mathrm{~d}^{-1}$ in Sep-

433 Oct, and the 24-hour antecedent rainfall for the October sampling was $2 \mathrm{~cm}$ (up

434 from $\leq 0.5 \mathrm{~cm}$ in other samplings). Streamflow increased from $0.4 \mathrm{~cm}^{3} \mathrm{~s}^{-1}$ in July-

435 August to $0.7-0.8 \mathrm{~cm}^{3} \mathrm{~s}^{-1}$ in Sep-Oct. Despite these relatively modest increases,

436 canal-wide average salinity dropped to $8 \mathrm{ppt}$ and the average silica concentrations

437 in Sep-Oct reached their highest concentrations (223-244 $\mu \mathrm{M})$. Phosphate

438 displayed only a small local peak in average concentration $(2 \mu \mathrm{M})$. Canal-wide

439 average concentrations of $v v h A$ reached a maximum during this event from 350

440 (range 67-3,500 gene copies $\mathrm{mL}^{-1}$ in September to an average of 2,700 (range 170 to

441 13,700) gene copies $\mathrm{mL}^{-1}$ in October. The average concentration in October was

442 significantly higher than at any other monthly sampling (ANOVA, post-hoc Tukey, $p$

$443 \leq .0005)$. At the subsequent sampling 15 days later (November), rainfall had

444 stopped, streamflow, phosphate and silica had declined, average salinity had

445 increased to $29 \mathrm{ppt}$ and $v v h A$ was at the lowest average concentration of the study

446 with an average of 20 (range 7-63) gene copies $\mathrm{mL}^{-1}$ across all sites.

447 A second, more pronounced drop in salinity occurred in December 2008 in

448 response to heavy rainfall recorded at both the coastal and Mānoa valley rain

449 gauges, resulting in the highest recorded streamflow $\left(2.6 \mathrm{~m}^{3} \mathrm{~s}^{-1}\right)$, minima in salinity

450 (3 ppt) and silica (34 $\mu \mathrm{M})$, and the highest average phosphate concentration (2.9

$451 \mu \mathrm{M}$ ). In contrast to the previous freshening event, $v v h A$ was not significantly

452 elevated (61 gene copies $\mathrm{mL}^{-1}$ ) and was near the overall study average.

453 A third freshening event occurred at the time of the last sampling in March

4542009 as a result of heavy rainfall in Mānoa Valley, but not at the coast. Streamflow

$455\left(1.3 \mathrm{~m}^{3} \mathrm{~s}^{-1}\right)$ was above average and intermediate between the first and second

456 events, and salinity was again significantly reduced (4 ppt). The effects on

457 phosphate $(1.3 \mu \mathrm{M})$ and silica $(87 \mu \mathrm{M})$ were modest, with phosphate being just

458 above the long-term average and silica just below. The mean concentration of $v v h A$ 
459 reached its third highest level at this time reaching 175 (range 22-811) gene copies

$460 \mathrm{~mL}^{-1}$ after steadily increasing each month from the lowest value in November.

461 Multiple linear regression was used to determine which subset of variables

462 best predicted canal-wide average $\log (v v h A)$ concentrations. The model resulting

463 from the best subset out of all combinations of twelve possible variables was:

$$
\log [v v h A]_{\text {avg }}=-1.125 \bullet \text { Streamflow }-0.07633 \bullet \text { Salinity }+0.00502 \bullet \text { Silica }+0.00151 \bullet P C+3.522
$$

467 where streamflow is in units of $\mathrm{m}^{3} \mathrm{~s}^{-1}$, and salinity, silica, and particulate carbon

468 (PC) are in units of $\mu \mathrm{M}$. All variables are the geometric means for all sites in the 469 canal for each monthly sampling $(n=13)$. Linear regression of the observed vs.

470 predicted $v v h A$ suggests that $97 \%$ of the canal-wide average variation in $v v h A$ could 471 be explained with the selected variables (Fig. 8a).

472 A second simpler model using a minimum of readily measurable variables

473 (salinity and rainfall) was also constructed:

$$
\log [v v h A]_{\text {avg }}=-0.162 \cdot \text { rainfall }-0.0956 \cdot \text { salinity }+4.348
$$

477 where rainfall is average rainfall in cm for the prior 24 hours at the Mānoa Valley

478 gauge, and salinity is canal-wide average salinity in ppt. This simpler model

479 explained $83 \%$ of the variability in average log-transformed concentrations of $v v h A$ 480 (Fig. 8b).

\section{DISCUSSION}

\section{Temporal and spatial variability of $\boldsymbol{V}$. vulnificus}

$483 \quad$ V. vulnificus, as inferred from $v v h A$ gene, was consistently detected

484 throughout the year in the Ala Wai Canal and Harbor system, but varied

485 dramatically over space and time. Sampling on different temporal scales showed

486 minimal variation in $V$. vulnificus within a day, but dramatic and stochastic

487 variations on longer time scales and among sites. This suggests that factors with 
488 regular intra-day variations (e.g. tides, or daily changes in temperature and primary

489 productivity driven by insolation) had relatively little influence on concentrations of

490 V. vulnificus. The largest absolute change in the canal-wide average $v v h A$

491 concentrations seen over the entire study occurred in a span of 2 weeks. The

492 observation that $V$. vulnificus concentrations were higher on average in the rainy vs.

493 dry season, yet the lowest average concentration recorded in the study also

494 occurred in the rainy season within weeks of the highest abundances, suggests that

495 freshwater input, which occurs stochastically, but with an underlying strong

496 seasonal component, is the most significant contributor to variability in $V$. vulnificus

497 abundance in this environment.

498 The results support an earlier hypothesis (21) that in tropical and some

499 subtropical climates, where the temperature range is narrow and persistently

500 warm, salinity is a stronger determinant than temperature of $V$. vulnificus

501 abundance. This is consistent with the seasonal variation in V. vulnificus in oysters in

502 India, which is not related to temperature, but by summer monsoonal rains

503 lowering salinity (47). In Hawai'i, with its rainy season in winter months, there is

504 thus a tendency toward a seasonal cycle in V. vulnificus abundance that is inverted

505 from the pronounced temperature-driven cycle found at higher latitudes and the

506 monsoon-driven cycle in India.

\section{Variable sources and influence of freshwater inputs}

508 The two major sources of freshwater to the Ala Wai canal are surface runoff

509 (primarily point source from streams and storm drains) and groundwater seeps.

510 Compared to surface runoff, groundwater in Hawai'i tends to be enriched in silica as

511 a result of prolonged water-rock interactions (48) and depleted in phosphate as a

512 result of interactions with lateritic soils containing high concentrations of iron and

513 aluminum oxyhydroxides $(48,49)$. These differences, along with information on

514 rainfall and streamflow, are helpful in identifying the primary source of the

515 freshwater entering the canal. In the factor analysis, Factor 1 may be interpreted as

516 a latent variable for groundwater (high loading for silica, but low for phosphate),

517 and Factor 2 as a latent variable for (negative) surface runoff (high, but opposing, 
518 loading of salinity and phosphate). Plots of the loading scores reinforce the

519 observation that $V$. vulnificus tended to be highest at moderate salinities and suggest

520 that groundwater was a relatively more important source of freshwater input under

521 those conditions (low streamflow, but elevated silica). When rainfall was highest,

522 surface runoff contributed more to freshwater input (highest streamflows with high

523 phosphate, low silica) and was associated with lower concentrations of vvhA.

$524 \quad$ This variable relationship between $v v h A$ and freshwater source was also

525 discernible in the temporal changes in variables when averaged across all canal

526 sites. Of the three major freshening events, the first, with relatively high silica and

527 low phosphate, suggests a significant contribution from groundwater. This is

528 consistent with the observation of significant drops in salinity despite only modest

529 increases in stream flow compared to the summer months. This presumed increase

530 in groundwater input appears to have been driven by a moderate increase in

531 monthly average rainfall in both September and October, coupled with a modest

532 increase in average rainfall during the 24 hours preceding sampling that was

533 greater at higher elevations in the watershed than locally.

$534 \quad$ The second freshening event, with a high concentration of phosphate but low

535 silica, appears to be dominated by surface runoff, resulted from a Kona storm on the

536 south shore of Oahu (38). A Kona storm is a rain event that deviates from the

537 normal northeasterly trade-wind driven patterns that govern Hawaii's weather and

538 occurs when southwestern Kona winds bring heavy rains to the southern shore of

539 Oahu. This storm resulted in unusually high rainfall, both higher in the watershed

540 and locally, in the 24 hours prior to sampling.

541 The third freshening event on March 10, 2009 appears to have a source

542 signature that is intermediate to the two prior events in terms of stream flow and

543 silica. This is consistent with an average rainfall in the preceding 24 hours in the

544 watershed that was high enough to increase downstream runoff and groundwater

545 discharge into the canal (as in the previous event), but with limited local

546 precipitation that, unlike the previous event, did not contribute appreciably to

547 surface runoff. 
$548 \quad$ The concentrations of $v v h A$ during these three events suggest that the 549 magnitude, if not the sources, of the freshwater input to the canal has a large 550 influence on V. vulnificus abundances. The mixing of freshwater with the seawater in 551 the canal is expected to have competing influences on $V$. vulnificus, because it 552 simultaneously alters temperature, salinity, and residence time. At sustained, 553 moderate levels of freshwater input (such as that from ground water intrusion 554 driven by moderate rainfall higher in the watershed), both the temperature drop 555 and decrease in residence time are relatively small, but the freshening is sufficient 556 to result in salinities that are optimal for $V$. vulnificus, thus explaining the unusually 557 high abundance of $V$. vulnificus in September and October 2008. During unusually 558 intense storms, especially with high rainfall lower in the watershed (December 559 2008), the very high levels of surface runoff appear to suppress abundances of $V$. 560 vulnificus in the canal. This is likely a result of the simultaneous reduction in growth 561 rate (caused by decreases in both temperature and salinity to below optimum) and 562 reduced residence time of water in the canal. Gonzalez (1971)(36), for example, 563 observed an inverse relationship between streamflow and residence time of runoff 564 waters in the Ala Wai Canal.

565 Although intense storms can temporarily suppress the canal-wide average 566 concentrations of $V$. vulnificus in the canal/harbor system, the actual changes are 567 site-specific. We observed, for example, that during the December 2008 storm, $V$. 568 vulnificus abundance, despite a lower canal-wide average, was higher than average 569 at Site 15, the most seaward site located in the Ala Wai Boat Harbor. In this location, 570 salinity was temporarily reduced to 13 (in the optimal range for $V$. vulnificus)

571 compared to the typical average salinity for this site of $\geq 30$ (38). Salinity remained 572 below the average in the harbor for 16 hours following the cessation of rainfall. This 573 suggests that the sites posing the highest risk of infection by $V$. vulnificus will vary 574 depending on the rainfall patterns and can even include the harbor which usually 575 had some of lowest concentrations. This condition-dependent elevated risk in the 576 harbor is consistent with the unfortunate incident of infection and death of an 577 individual who had open wounds exposed to harbor water following a long period 578 of intense rainfall (50). 


\section{Patterns of $\boldsymbol{V}$. vulnificus strain abundance}

$580 \quad$ C-type $V$. vulnificus are the strains most frequently associated with infections

581 in humans (9), but are often less abundant than E-type in environmental samples (9,

582 51). This appeared to be the case in our study site with C-type $V$. vulnificus

583 accounting for an estimated $25 \%$ on average. The percentage was highly variable,

584 however, and our observation that the C-type V. vulnificus tended to make up a

585 higher percentage of the total at higher salinities (despite declining in absolute

586 abundance) is consistent with some previous observations. Williams et al. (2017),

587 for example, observed a negative influence of salinity on the abundance of E-type

588 and C-type strains, but the effect was greater for E-type (51). Lin and Schwartz

589 (2003) observed that when temperature decreased and salinity increased, in situ

590 abundance of 16S rRNA A-type strains (analogous to E-type) decreased while B-type

591 (analogous to C-type) increased and temporarily became the dominant genotype

592 (52). Other studies in high salinity (> $32 \mathrm{ppt)}$ coastal waters have found that either a

593 majority (7) or all (53) of the isolates obtained were of B-type (C-Type). These

594 observations support the contention that these different genotypes reflect distinct

595 ecotypes, with the C-type having greater stress tolerance (10).

596 Multiple linear regression analysis was used to model V. vulnificus abundance

597 using a reduced number of variables. Although these variables explained a

598 significant percentage of the variability in $V$. vulnificus abundance, a great deal of

599 sample-to-sample variability remains unexplained, which is not uncommon $(21,26)$.

600 Predicting system-wide average concentrations of V. vulnificus, on the other hand,

601 was much more successful. A model with the best subset of four variables explained

$60297 \%$ of the variability, and much simpler model relying on only two readily

603 obtainable measurements (rainfall and salinity), still accounted for much of the

604 variability and might prove more useful in practice for predicting relative risk from

$605 V$. vulnificus of exposure to waters of the canal and harbor.

606 The high level of predictability for system-wide average $V$. vulnificus is similar to

607 that achieved using logistic regression to predict $v \nu h A$ as a binary response variable

608 either as presence vs. absence (46) or low vs. high abundance (54). Improvements 
609 in the prediction of $V$. vulnificus at higher resolution may be realized by combining

610 biological population models for $V$. vulnificus with physical models of coastal

611 circulation (54). In the meantime, the results from this study provide a detailed

612 description of the ecology of $V$. vulnificus in tropical estuarine waters of Hawai'i. The

613 results are a useful first step toward predicting and, ultimately taking steps to

614 mitigate, the incidence of $V$. vulnificus infections.

\section{ACKNOWLEDGMENTS}

616 We are grateful to G. Walker and B. Marchant for assistance with sample collection

617 and A. Culley for support and advice. We thank Hawai'i Ocean Time-series program

618 staff for support with processing PC/PN samples and R. Briggs for advice on

619 chemical measurements. This work was supported by grants from Hawai'i Sea Grant

$620(2009,2012)$ and the National Science Foundation (OCE05-54768, OCE08-26650)

621 and NOAA Ocean Observing (NA07NOS4730207).

\section{REFERENCES}

623 1. Oliver J. 2006. Vibrio vulnificus, p. 349-363. In Thompson, F, Austin, B, Swings, J 624 (eds.), The Biology of Vibrios. American Society for Microbiology (ASM),

625 Washington, D.C.

626 2. Horseman MA, Surani S. 2011. A comprehensive review of Vibrio vulnificus: an 627 important cause of severe sepsis and skin and soft-tissue infection. Int J Infect 628 Dis 15:e157-e166.

629 3. Jones MK, Oliver JD. 2009. Vibrio vulnificus: disease and pathogenesis. Infect $630 \quad$ Immun 77:1723-1733.

631 4. Oliver JD. 2005. Wound infections caused by Vibrio vulnificus and other marine 632 bacteria. Epidemiol Infect 133:383-391. 
633 5. Oliver JD. 2015. The biology of Vibrio vulnificus. Microbiol Spectr 3:VE-00016342014.

635 6. Baker-Austin C, Oliver JD. 2018. Vibrio vulnificus: new insights into a deadly 636 opportunistic pathogen. Environ Microbiol 20:423-430.

637 7. Kim MS, Jeong HD. 2001. Development of 16S rRNA targeted PCR methods for 638 the detection and differentiation of Vibrio vulnificus in marine environments. 639 Aquaculture 193:199-211.

640 8. Nilsson WB, Paranjype RN, DePaola A, Strom MS. 2003. Sequence 641 polymorphism of the 16S rRNA gene of Vibrio vulnificus is a possible indicator 642 of strain virulence. J Clin Microbiol 41:442-446.

643 9. Rosche TM, Yano Y, Oliver JD. 2005. A rapid and simple PCR analysis indicates 644 there are two subgroups of Vibrio vulnificus which correlate with clinical or 645 environmental isolation. Microbiol Immunol 49:381-389.

646 10. Rosche TM, Binder EA, Oliver JD. 2010. Vibrio vulnificus genome suggests two 647 distinct ecotypes. Environ Microbiol Rep 2:128-132.

648 11. Sanjuán E, Fouz B, Oliver JD, Amaro C. 2009. Evaluation of genotypic and 649 phenotypic methods to distinguish clinical from environmental Vibrio vulnificus 650 strains. Appl Environ Microbiol 75:1604-1613.

651 12. Kelly MT. 1982. Effect of temperature and salinity on Vibrio (Beneckea) 652 vulnificus occurrence in a Gulf Coast environment. Appl Environ Microbiol $653 \quad 44: 820-824$.

654 13. O’Neill KR, Jones SH, Grimes DJ. 1992. Seasonal incidence of Vibrio vulnificus in 655 the Great Bay estuary of New Hampshire and Maine. Appl Environ Microbiol $656 \quad 58: 3257-3262$. 
657 14. Kaysner CA, Abeyta C, Wekell MM, DePaola A, Stott RF, Leitch JM. 1987.

658 Virulent strains of Vibrio vulnificus isolated from estuaries of the United States

659 West Coast. Appl Environ Microbiol 53:1349-1351.

660 15. Høi L, Larsen JL, Dalsgaard I, Dalsgaard A. 1998. Occurrence of Vibrio vulnificus

661 biotypes in Danish marine environments. Appl Environ Microbiol 64:7-13.

662 16. Motes ML, DePaola A, Cook DW, Veazey JE, Hunsucker JC, Garthright WE,

663 Blodgett RJ, Chirtel SJ. 1998. Influence of water temperature and salinity on

664 Vibrio vulnificus in Northern Gulf and Atlantic Coast oysters (Crassostrea

665 virginica). Appl Environ Microbiol 64:1459-1465.

666 17. Lin M, Payne DA, Schwarz JR. 2003. Intraspecific diversity of Vibrio vulnificus in

667 Galveston Bay water and oysters as determined by randomly amplified

668 polymorphic DNA PCR. Appl Environ Microbiol 69:3170-3175.

669 18. Pfeffer CS, Hite MF, Oliver JD. 2003. Ecology of Vibrio vulnificus in estuarine

670 waters of eastern North Carolina. Appl Environ Microbiol 69:3526-3531.

671 19. Randa MA, Polz MF, Lim E. 2004. Effects of temperature and salinity on Vibrio

672 vulnificus population dynamics as assessed by quantitative PCR. Appl Environ

673 Microbiol 70:5469-5476.

674 20. Rivera S, Lugo T, Hazen TC. 1989. Autecology of Vibrio vulnificus and Vibrio

675 parahaemolyticus in tropical waters. Water Res 23:923-931.

676 21. Lipp E, Rodriguez-Palacios C, Rose J. 2001. Occurrence and distribution of the

677 human pathogen Vibrio vulnificus in a subtropical Gulf of Mexico estuary.

$678 \quad$ Hydrobiologia 460:165-173.

679 22. Chase E, Harwood VJ. 2011. Comparison of the effects of environmental 680 parameters on growth rates of Vibrio vulnificus biotypes I, II, and III by culture 681 and quantitative PCR analysis. Appl Environ Microbiol 77:4200-4207. 
682 23. Ramirez GD, Buck GW, Smith AK, Gordon KV, Mott JB. 2009. Incidence of Vibrio 683 vulnificus in estuarine waters of the south Texas Coastal Bend region. J Appl 684 Microbiol 107:2047-2053.

24. Johnson CN, Flowers AR, Noriea NF, Zimmerman AM, Bowers JC, DePaola A, 686 Grimes DJ. 2010. Relationships between environmental factors and pathogenic vibrios in the northern Gulf of Mexico. Appl Environ Microbiol 76:7076-7084.

25. Nigro OD, Hou A, Vithanage G, Fujioka RS, Steward GF. 2011. Temporal and spatial variability in culturable pathogenic Vibrio spp. in Lake Pontchartrain, Louisiana, following hurricanes Katrina and Rita. Appl Environ Microbiol

26. Wetz JJ, Blackwood AD, Fries JS, Williams ZF, Noble RT. 2014. Quantification of Vibrio vulnificus in an estuarine environment: a multi-year analysis using qPCR. 77:5384-5393.

27. Dziuban EJ, Liang JL, Craun GF, Hill V, Yu PA, Painter J, Moore MR, Calderon RL, Roy SL, Beach MJ, Control C for D, CDC P. 2006. Surveillance for waterborne disease and outbreaks associated with recreational water-United States, 2003-2004. MMWR Surveill Summ Morb Mortal Wkly Rep Surveill Summ CDC

28. Yoder JS, Hlavsa MC, Craun GF, Hill V, Roberts V, Yu PA, Hicks LA, Alexander NT, Calderon RL, Roy SL, Beach MJ, Control C for D, CDC P. 2008. Surveillance for waterborne disease and outbreaks associated with recreational water use and other aquatic facility-associated health events-United States, 2005-2006. MMWR Surveill Summ Morb Mortal Wkly Rep Surveill Summ CDC 57:1-29. Hicks LA, Newton A, Hilborn ED, Wade TJ, Beach MJ, Yoder JS, CDC. 2011. 
associated with recreational water-United States, 2007-2008. MMWR Surveill

30. Vithanage G. 2011. The prevalence and public health significance of human pathogenic Vibrio species (V. cholera, V.vulnificus, V. parahaemolyticus, $V$. alginolyticus) in Hawai'i's diverse tropical coastal environments. PhD Thesis, University of Hawai'i at Mānoa, Honolulu.

714 31. Viau EJ, Goodwin KD, Yamahara KM, Layton BA, Sassoubre LM, Burns SL, Tong 715 H-I, Wong SHC, Lu Y, Boehm AB. 2011. Bacterial pathogens in Hawaiian coastal 716 streams-associations with fecal indicators, land cover, and water quality. $717 \quad$ Water Res 45:3279-3290.

718 32. Giambelluca TW, Chen Q, Frazier AG, Price JP, Chen YL, Chu PS, Eischeid JK, 719 Delparte DM. 2013. Online rainfall atlas of Hawai'i. Bull Am Meteorol Soc $720 \quad 94: 313-316$.

721 33. De Carlo EH, Anthony SS. 2002. Spatial and temporal variability of trace 722 element concentrations in an urban subtropical watershed, Honolulu, Hawaii. 723 Appl Geochem 17:475-492.

724 34. De Carlo EH, Anthony SS. 2002. Spatial and temporal variability of trace 725 element concentrations in an urban subtropical watershed, Honolulu, Hawaii. Appl Geochem 17:475-492.

35. Laws EA, Doliente D, Hiayama J, Hokama M-L, Kim K, Li D, Minami S, Morales C. 728 1993. Hypereutrophication of the Ala Wai Canal, Oahu, Hawaii: prospects for cleanup. Pac Sci 47:59-75.

730 36. Gonzales F. 1971. A descriptive study of the physical oceanography of the Ala 731 Wai Canal. PhD Thesis, University of Hawa'i at Mānoa, Honolulu. 
733

734

735

736

737

738

739

740

741

742

743

744

745

746

747

748

749

750

751

752

753

754

755

756

757

758

continuous flow automated analysis of seawater nutrients (phosphate, nitrate, nitrite and silicic acid) in the WOCE Hydrographic Program and the Joint Global Ocean Flux Study. 93-1. Technical Report, Oregon State University, College of Oceanography, Descriptive Chemical Oceanography Group.

38. Tomlinson MJ, De Carlo EH, McManus MA, Pawlak G, Steward GF, Sansone FJ, Nigro OD, Timmerman RE, Patterson J, Jaramillo S, Ostrander CE. 2011. Characterizing the effects of two storms on the coastal waters of O'ahu, Hawai'i, using data from the Pacific Islands Ocean Observing System. Oceanography 24:182-199.

39. Karl DM, Dore JE, Hebel DV, Winn C. 1991. Procedures for particulate carbon, nitrogen, phosphorus and total mass analyses used in the US-JGOFS Hawaii Ocean Time-series program, p. 71-77. In Hurd, DC, Spencer, DW (eds.), Marine Particles: Analysis and Characterization. Washington, D.C.

40. Strickland JDH, Parsons TR. 1972. A practical hand book of seawater analysis, 2nd ed. Fisheries Research Board of Canada Bulletin 157.

41. Berthelet M, Whyte LG, Greer CW. 1996. Rapid, direct extraction of DNA from soils for PCR analysis using polyvinylpolypyrrolidone spin columns. FEMS Microbiol Lett 138:17-22.

42. Campbell MS, Wright AC. 2003. Real-time PCR analysis of Vibrio vulnificus from oysters. Appl Environ Microbiol 69:7137-7144.

43. Baker-Austin C, Gore A, Oliver JD, Rangdale R, McArthur JV, Lees DN. 2010. Rapid in situ detection of virulent Vibrio vulnificus strains in raw oyster matrices using real-time PCR. Environ Microbiol Rep 2:76-80.

44. Bustin SA, Benes V, Garson JA, Hellemans J, Huggett J, Kubista M, Mueller R, Nolan T, Pfaffl MW, Shipley GL, Vandesompele J, Wittwer CT. 2009. The MIQE Guidelines: Minimum information for publication of quantitative real-time PCR 
experiments. Clin Chem 55:611-622.

760 45. Deeb R, Tufford D, Scott GI, Moore JG, Dow K. 2018. Impact of climate change on Vibrio vulnificus abundance and exposure risk 1-15.

762 46. Banakar V, Constantin de Magny G, Jacobs J, Murtugudde R, Huq A, Wood RJ,

763 Colwell RR. 2011. Temporal and spatial variability in the distribution of Vibrio

764 vulnificus in the Chesapeake Bay: a hindcast study. EcoHealth 8:456-467.

765 47. Parvathi A, Kumar HS, Karunasagar I, Karunasagar I. 2004. Detection and enumeration of Vibrio vulnificus in oysters from two estuaries along the southwest coast of India, using molecular methods. Appl Environ Microbiol

48. De Carlo EH, Hoover DJ, Young CW, Hoover RS, Mackenzie FT. 2007. Impact of storm runoff from tropical watersheds on coastal water quality and productivity. Appl Geochem 22:1777-1797.

49. Goldberg S, Sposito G. 1984. Chemical model of phosphate adsorption by soils: 70:6909-6913.

774 50. Creamer B. 2006. Bacteria draw attention of UH scientists. Honol Advert. $775 \quad$ Honolulu.

776 51. Williams TC, Froelich BA, Phippen B, Fowler P, Noble RT, Oliver JD. 2017. 777 Different abundance and correlational patterns exist between total and presumed pathogenic Vibrio vulnificus and V. parahaemolyticus in shellfish and 779 waters along the North Carolina coast. FEMS Microbiol Ecol 93:125-11.

780 52. Lin M, Schwarz JR. 2003. Seasonal shifts in population structure of Vibrio 781 vulnificus in an estuarine environment as revealed by partial 16S ribosomal $782 \quad$ DNA sequencing. FEMS Microbiol Ecol 45:23-27. 
783 53. Maugeri TL, Carbone M, Fera MT, Gugliandolo C. 2006. Detection and

784 differentiation of Vibrio vulnificus in seawater and plankton of a coastal zone of

785 the Mediterranean Sea. Res Microbiol 157:194-200.

786 54. Jacobs JM, Rhodes M, Brown CW, Hood RR, Leight A, Long W, Wood R. 2014.

$787 \quad$ Modeling and forecasting the distribution of Vibrio vulnificus in Chesapeake

788 Bay. J Appl Microbiol 117:1312-1327. 
790 Table 1. Variables measured on individual samples, the number of samples measured, and the

791 geometric mean (geomean), mean, median, minimum (min) and maximum (max) values for each

792 (reported to two significant digits).

\begin{tabular}{lcrrrrrrr}
\hline Variable & units & $\mathbf{n}$ & Geomean & Mean & Median & S.D. & Min & Max \\
\hline Temperature & ${ }^{\circ} \mathrm{C}$ & 242 & 27 & 27 & 27 & 2.6 & 19 & 32 \\
Salinity & $\mathrm{ppt}$ & 243 & 20 & 24 & 28 & 9.7 & 1 & 36 \\
Nitrate & $\mu \mathrm{M}$ & 209 & 18 & 37 & 17 & 48 & 0.02 & 260 \\
Nitrite & $\mu \mathrm{M}$ & 211 & 0.47 & 0.59 & 0.47 & 0.47 & 0.04 & 3.3 \\
Ammonia & $\mu \mathrm{M}$ & 207 & 5.5 & 6.7 & 5.7 & 4.3 & 0.94 & 22 \\
Phosphate & $\mu \mathrm{M}$ & 211 & 1 & 1.3 & 0.95 & 1.1 & 0.2 & 8.7 \\
Silica & $\mu \mathrm{M}$ & 211 & 110 & 140 & 120 & 92 & 11 & 490 \\
Particulate Carbon & $\mu \mathrm{M}$ & 199 & 130 & 250 & 120 & 650 & 20 & 7500 \\
Particulate Nitrogen & $\mu \mathrm{M}$ & 199 & 16 & 26 & 14 & 51 & 2.6 & 560 \\
Chlorophyll $a$ & $\mu \mathrm{g} \mathrm{L} \mathrm{L}^{-1}$ & 194 & 7.6 & 19 & 7.3 & 43 & 0.4 & 500 \\
Total bacteria & $10^{9} \mathrm{cells} \mathrm{L}^{-1}$ & 219 & 4.2 & 4.8 & 4.7 & 2.3 & 0.47 & 11 \\
CaV blue $^{1}$ & $\mathrm{CFU} \mathrm{mL}^{-1}$ & 59 & 130 & 400 & 100 & 770 & 12 & 3904 \\
vvhA gene & copies mL $^{-1}$ & 239 & 68 & 330 & 60 & 1200 & 3.4 & 14000 \\
\hline
\end{tabular}

$793{ }^{1}$ culture-based blue colony forming units (CFU) when plating on CHROMagar Vibrio medium $(\mathrm{CaV})$

7942 qPCR-based estimates 


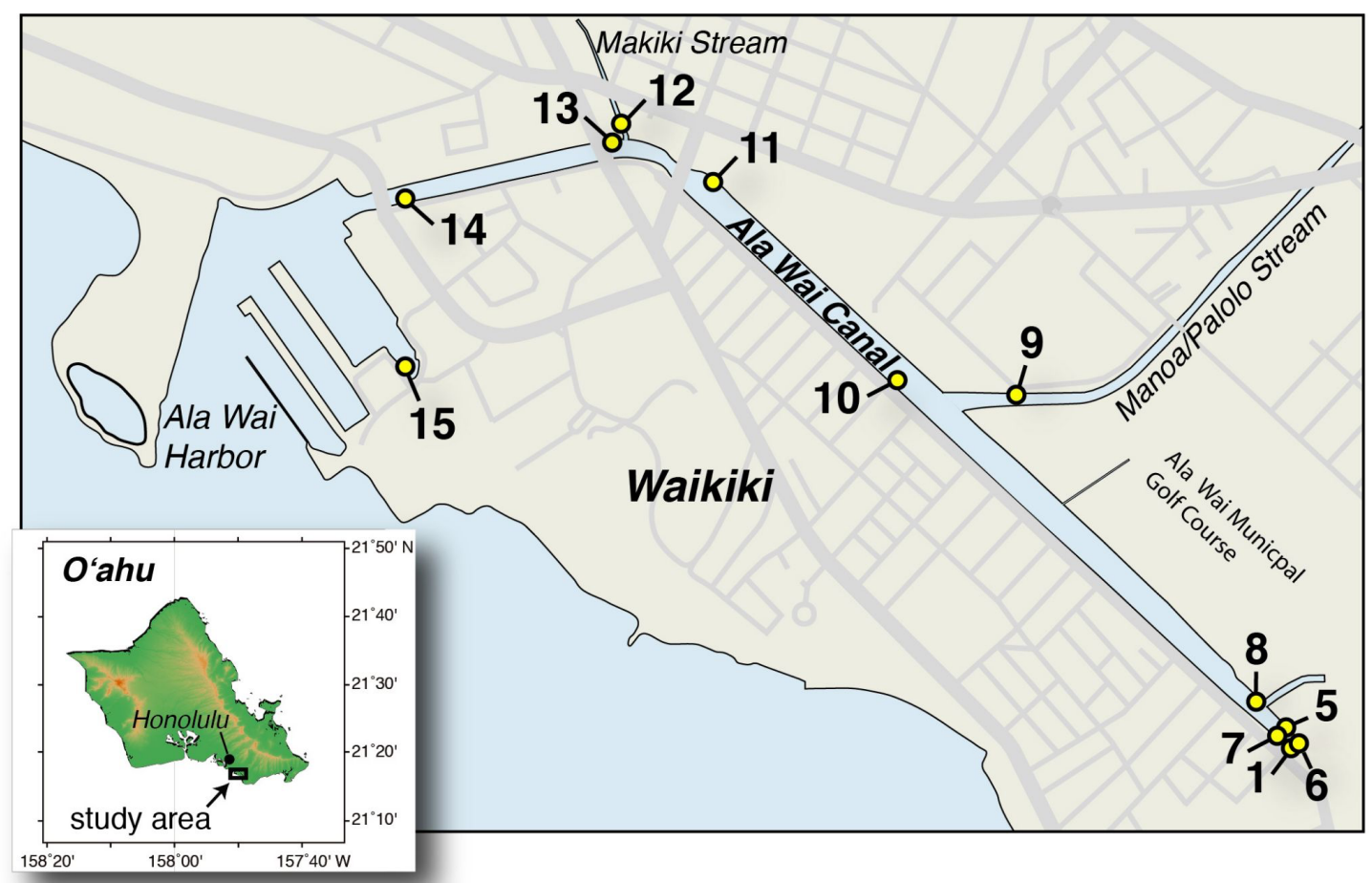

797 Fig. 1. Map of Samping Sites. Inset shows the general location of the canal on the

798 south shore of the island of O'ahu in the Hawaiian Island chain. Main map shows the 799 site numbers and position along the canal. Site 1 is at the closed end of the canal 800 with occasional input from surface runoff via storm drains. Sites 9 and 12 are at the 801 mouths of the Mānoa-Pālolo and Makiki Streams, respectively. 


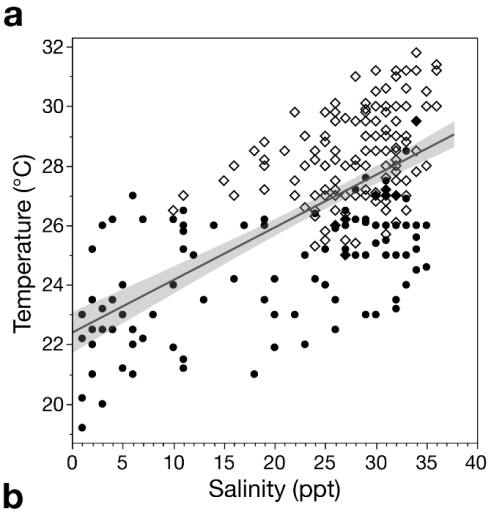

b

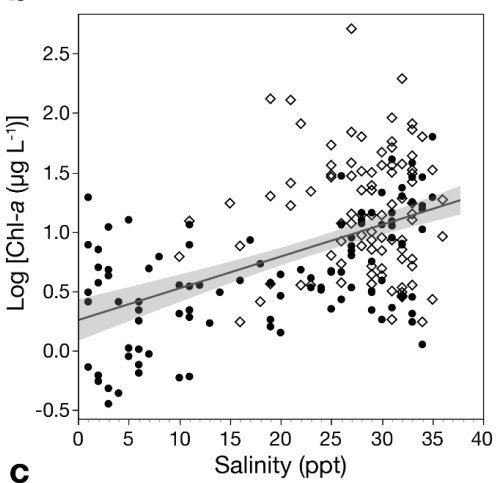

c

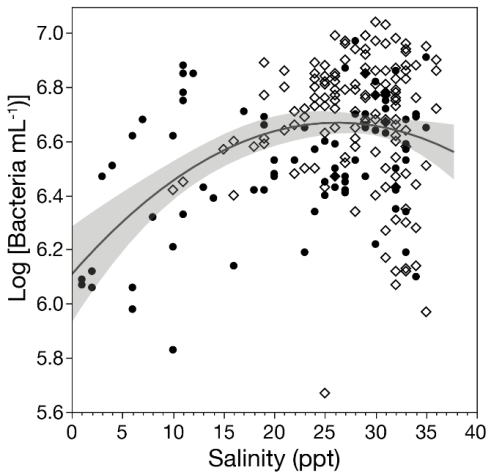

d
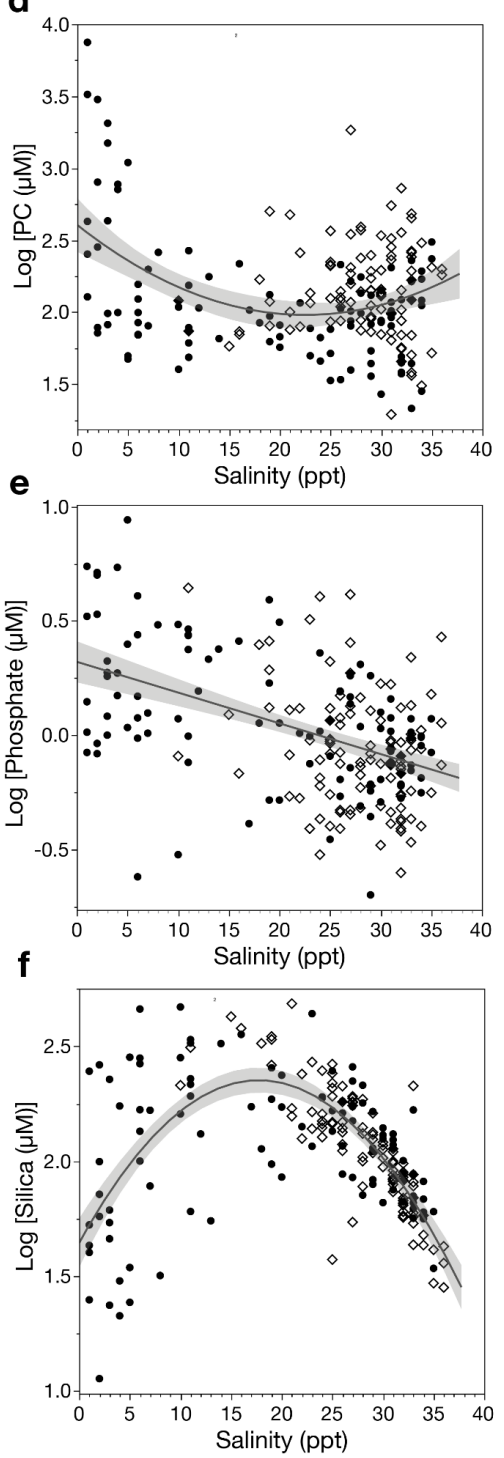

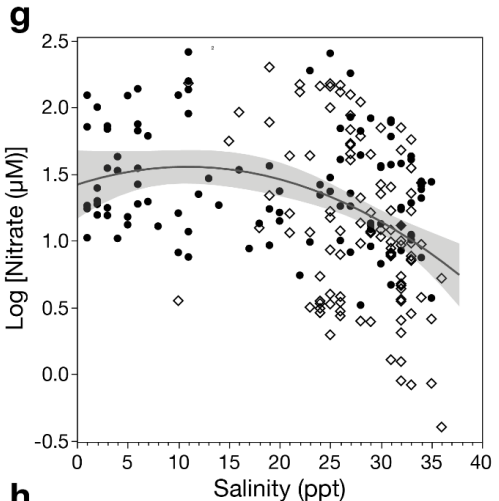

h
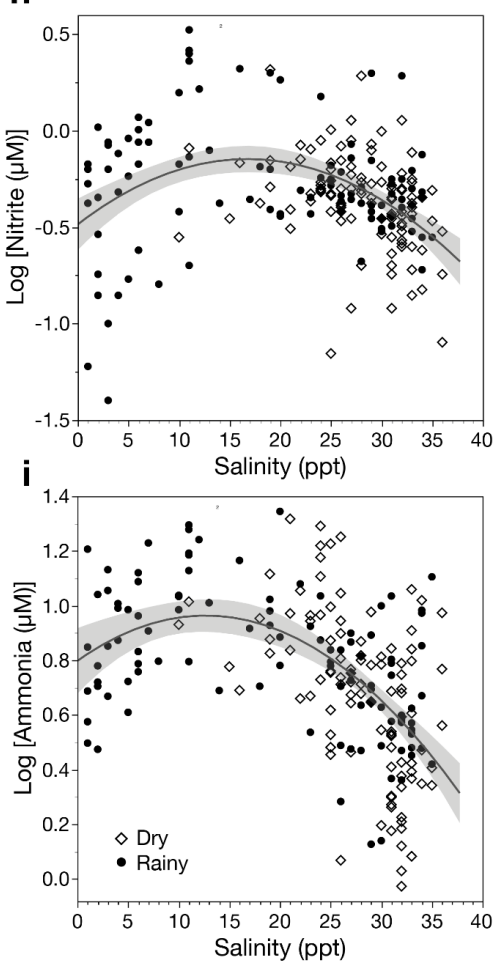

802

803

804

805

806

807

808

809

810

811

Fig. 2. Variability in measured biological and chemical properties of samples as a function of salinity in samples from the rainy (solid circles) and dry (open diamonds) seasons. Regressions against salinity are shown for (a) temperature $\left(\mathrm{r}^{2}=\right.$ 0.42), (b) Log chl $a\left(\mathrm{r}^{2}=0.24\right)$, (c) $\log$ bacteria $\left(\mathrm{r}^{2}=0.14\right),(\mathbf{d}) \log \mathrm{PC}\left(\mathrm{r}^{2}=0.13\right)$, (e) $\log$ phosphate $\left(\mathrm{r}^{2}=0.22\right),(\mathbf{f}) \log$ silica $\left(\mathrm{r}^{2}=0.463\right),(\mathrm{g}) \log$ nitrate $\left(\mathrm{r}^{2}=0.13\right),(\mathbf{h}) \log$ nitrite $\left(r^{2}=0.152\right)$, (i) $\log$ ammonia $\left(r^{2}=0.29\right)$. Regression lines and $95 \%$ confidence limits were fit using only first order terms unless addition of a quadratic term substantially improved $\mathrm{r}^{2}$ or reduced root mean square error. All fits were significant $(\mathrm{p}<.0001)$. 
812

813 Fig. 3. Heat maps illustrating spatial and temporal variability in V. vulnificus. Log vvhA

814 concentrations are color coded at each station over time for monthly, weekly, daily and

815 trihoral sampling events. The overall average $\log (v v h a)$ from all samplings of 1.8 is shown in

816 grey. Concentrations above average are in red and those below average in blue. The

817 samplings on different time scales are nested and the events that are overlapping in the

818 different graphs are indicated with black triangles and lines. a

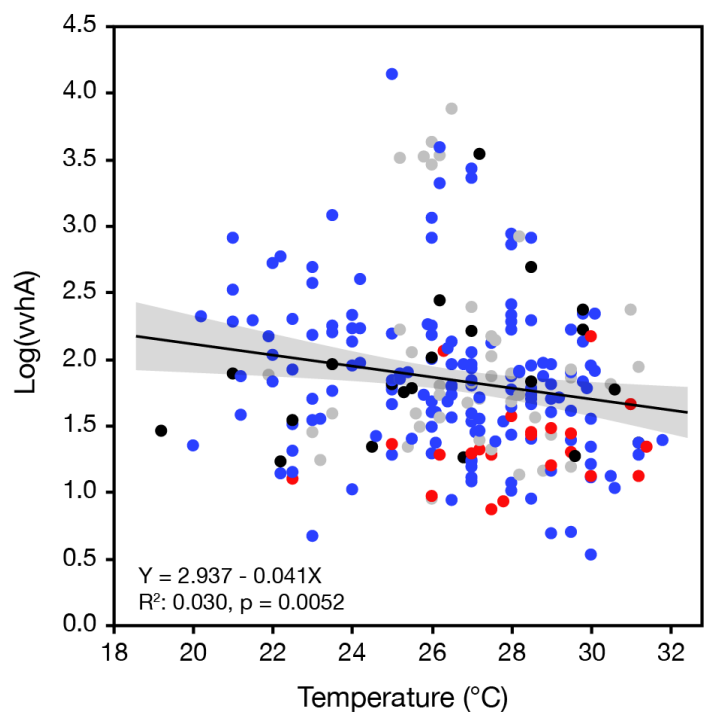

b

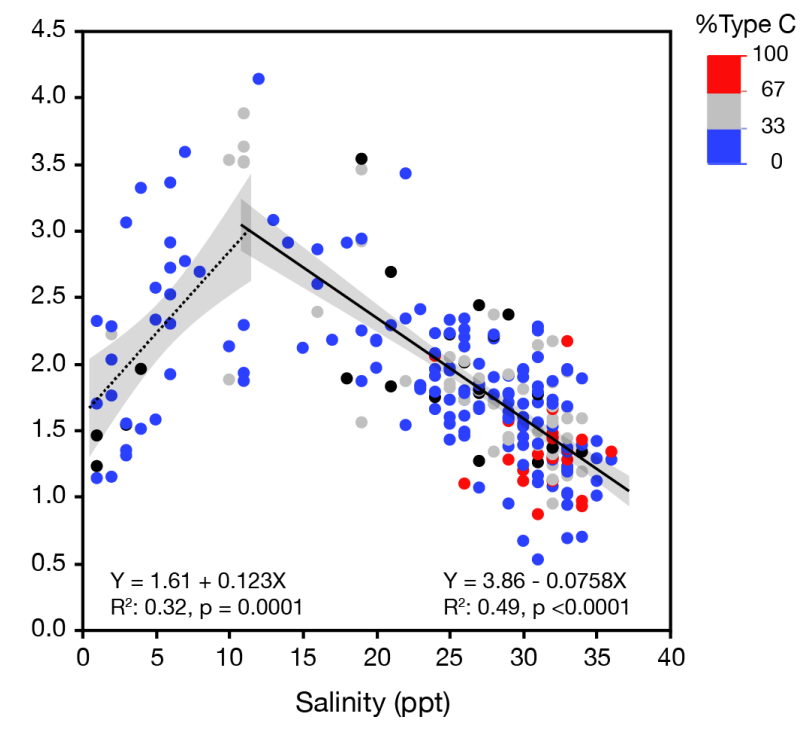

820 Fig. 4. Concentration of $v v h A$ as a function of $\mathbf{a})$ temperature or $\mathbf{b}$ ) salinity. The percentage

821 of total $v v h A$ that derives from "C-type" V. vulnificus was determined as the ratio of $v c g C$ (C-

822 type) and $v v h A$ (total V. vulnificus) gene concentrations and is indicated by the color scale.

823 Blue dots are samples dominated by E-type, red dots by C-type. Black dots are samples for

824 which the \% C-type could not be determined because of missing data. 
a

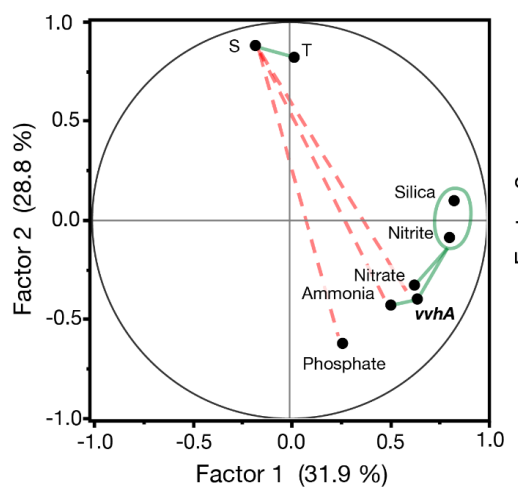

b

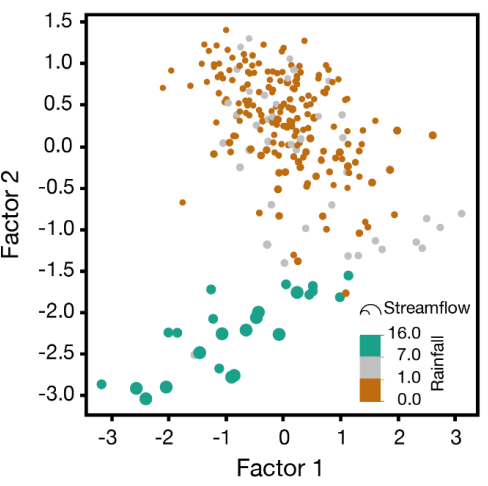

C

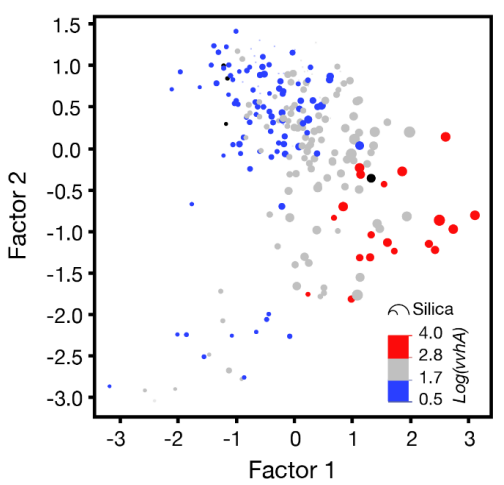

827 Fig. 5. Factor Analysis for $v v h A$, temperature, salinity, and nutrients. (a) The factor loading

828 plot for factors 1 and 2 (eigenvalues $>1$ ). Variables with a strong positive correlations ( $\mathrm{r} \geq$

$8290.4)$ are connected by green solid lines and those with strong negative correlation $(\mathrm{r} \leq 0.4)$

830 are connected by dashed red lines (b) Plot of the factor scores for the data with points

831 colored by 24-hr antecedent rainfall in Mānoa Valley (in cm) and scaled in size so area is

832 proporional to streamflow in the Mānoa-Pālolo Stream. (c) Plot of the factor scores with

833 data points colored according to $\log v v h A$ concentration and scaled in size so area is

834 proportional to silica concentration. 


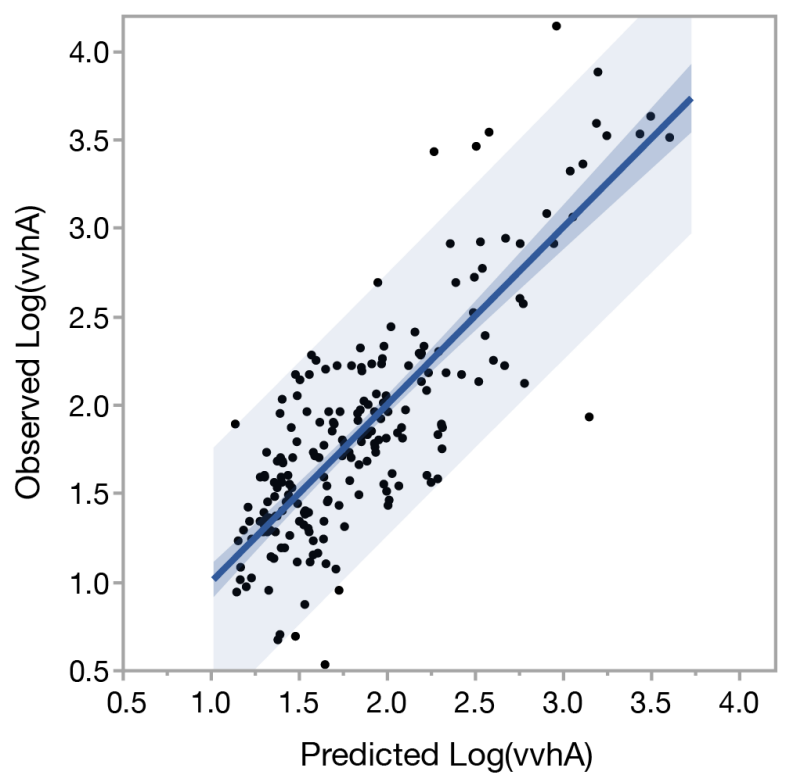

836 Fig. 6. Observed vs. predicted values of log transformed $v v h A$ gene copies per $\mathrm{mL}^{-1}$.

837 Predicted values are combined from two separate models (one for samples $<12 \mathrm{ppt}$, one for

$838 \geq 12 \mathrm{ppt}$ ). Predicted values are restricted to individual samples for which all of the predictor

839 variables were measured within a given salinity range $(n=204$ out of 239 in total). Darker

840 and lighter shading illustrates the 95\% confidence limits of the fit and prediction,

841 respectively. Combined, the models explain a significant amount of the variation in the

842 observations: $\mathrm{r}^{2}=0.661$, RMSE $=0.37$, F Test $(1,204)=396.90, \mathrm{p}<.0001$. 


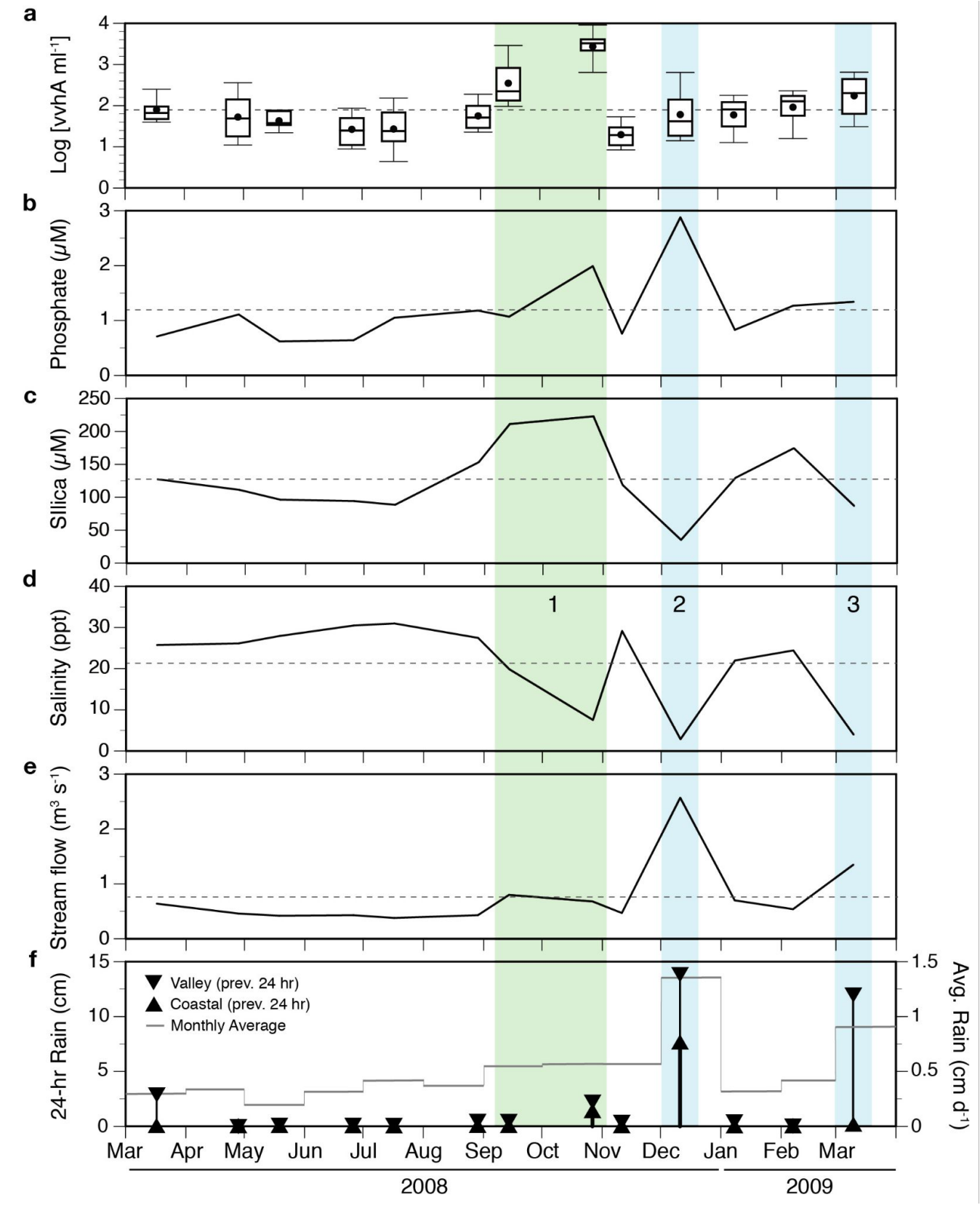

844 Fig. 7. Time series of variables in or influencing the Ala Wai Canal system. Shown are a)

845 variations of $v v h A$ concentrations as box plots of all log transformed values measured at

846 every site at each monthly sampling, canal-wide geometric means of b) phosphate, $\mathbf{c}$ )

847 salinity, d) silica, as well as e) streamflow in the Mānoa-Pālolo stream on the day of

848 sampling, and $\mathbf{f}$ ) rainfall in the 24-hr period preceding sampling as measured at the

849 Honolulu coastal (upward triangles) and Mānoa Valley rain gauges (downward triangles).

850 Daily rainfall average for the month is shown as the mean for both sites (grey line). Dashed

851 lines in a-e show the mean value over the time period. 

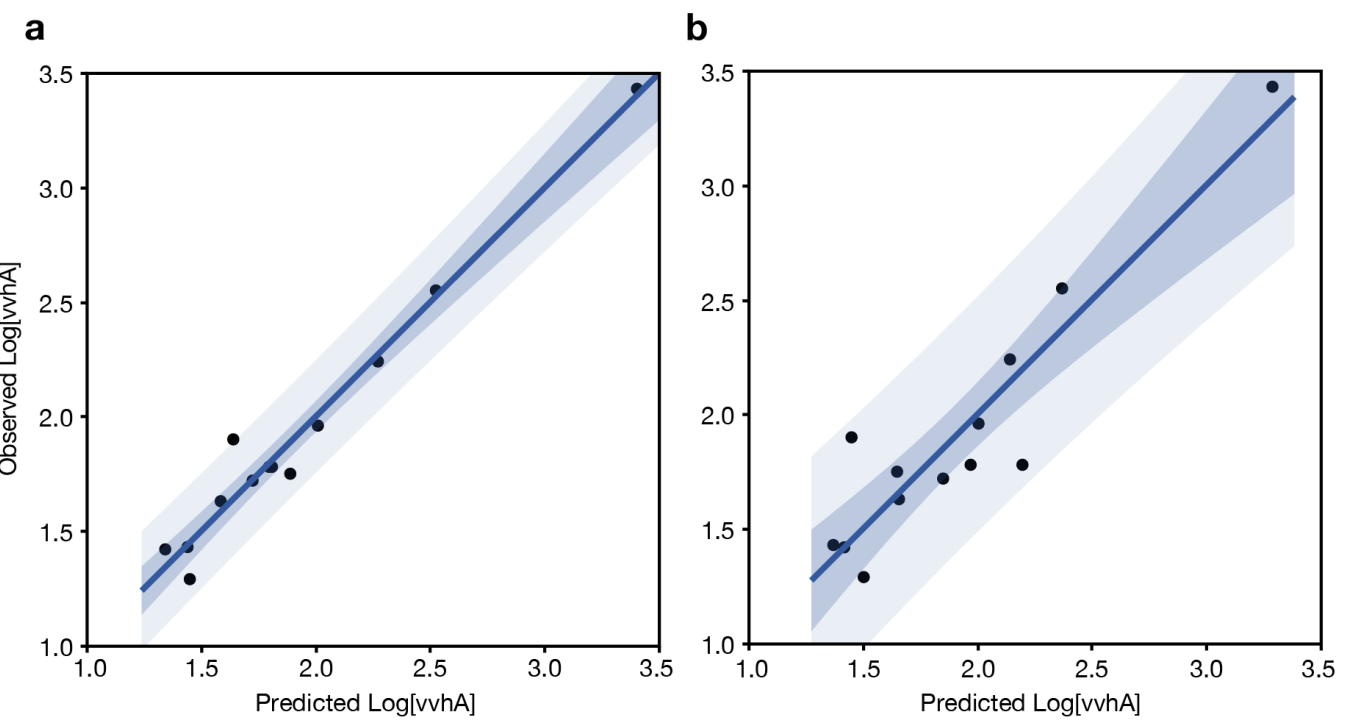

853 Fig. 8. Observed vs predicted canal-wide average of log-transformed $v v h A$ concentrations.

854 Predictions are derived from a) the best subset of variables (salinity, silica, streamflow,

855 particulate carbon) from generalized regression model $\left(\mathrm{r}^{2}=0.97\right.$; RMSE $=0.11 ; \mathrm{F}$ test $\mathrm{p}<$

856.0001 ) or $\mathbf{b}$ ) a restricted subset of two variables (rainfall and salinity) that are easily

857 measured autonomously $\left(r^{2}=0.86\right.$; RMSE $=0.22$; $\mathrm{F}$ test $\left.\mathrm{p}<.0001\right)$. Darker and lighter

858 shading illustrates the $95 \%$ confidence limits of the fit and prediction, respectively. 